\title{
Phytochemical Composition and Toxicity Evaluation of Camellia Sinensis (L.) O.Kuntze (Theaceae) (Green Tea) Leaves Collected from Mambila Beverages Ltd Nigeria
}

\author{
Cletus.A. Ukwubile ${ }^{1 *}$, Troy .S. Malgwi ${ }^{1}$, Musa .Y. Dibal ${ }^{1}$, Abdulqadir .B. Bababe ${ }^{2}$, Mathias .S. \\ Bingari ${ }^{3}$. \\ ${ }^{1}$ Department of Pharmacognosy, Faculty of Pharmacy, University of Maiduguri, Maiduguri, \\ Nigeria. \\ ${ }^{2}$ Department of Pharmaceutical Chemistry, Faculty of Pharmacy, University of Maiduguri, \\ Nigeria. \\ ${ }^{3}$ Department of Biological Sciences, Faculty of Sciences, Taraba State University Jalingo, \\ Nigeria.
}

*Corresponding Author: Cletus.A. Ukwubile, Department of Pharmacognosy, Faculty of Pharmacy, University of Maiduguri, Maiduguri, Nigeria.

\begin{abstract}
:
Context: Camellia sinensis leaves have been reported to have vital bioactive compounds that have been employed in therapeutic purposes as antioxidants and green tea.

Aims: To evaluate the phytochemical composition of leaf and determine the toxicity in mice.

Methods: Phytochemical screening of leaf extracts and toxicity studies were performed following standard procedures. Acute intoxication of $2000 \mathrm{mg} / \mathrm{kg}$ body weight (b.w.) leaf extract (p.o) in mice was carried out in three mice, and observed for signs of toxicity especially, the first 4 hours, and then 14 days. Subchronic doses of $300 \mathrm{mg} / \mathrm{kg}, 600 \mathrm{mg} / \mathrm{kg}, 900 \mathrm{mg} / \mathrm{kg}$ and $1200 \mathrm{mg} / \mathrm{kg} \mathrm{b.w.} \mathrm{were} \mathrm{administered} \mathrm{to} \mathrm{Swiss} \mathrm{albino} \mathrm{mice} \mathrm{orally} \mathrm{for}$ 28 days. Blood samples were collected from the mice by cardiac puncturing for toxicity profiles.

Results: Fractions from solvents indicate the presence of flavonoids, alkaloids, steroids, triterpenoids, carbohydrates and cardiac glycosides in ethyl acetate fraction. Acute intoxication of $2000 \mathrm{mg} / \mathrm{kg} \mathrm{b.w.} \mathrm{extract}$ mice showed that the leaf extract was well tolerated after 14 days. Serum biochemical parameter levels were within non-toxic range. Slight weight increase in organs were noticed in liver, kidney and heart after 28 days. Elevated serum $\mathrm{Na}+$ and $\mathrm{Cl}$ - levels were witnessed at higher doses. Partial organ congestions were also noticed in some organs.
\end{abstract}

Conclusion: The study showed that the leaf of C. sinensis contain phytochemicals that are safe for consumption. However, it should be administered at moderate doses to avoid some of the noted toxicological effects.

Keywords: Camellia sinensis, phytochemical composition, toxicity evaluation, Nigeria, Mambila beverages Ltd.

\section{INTRODUCTION}

\subsection{Use of Medicinal Plants in Nigeria's Health Care System}

Nature has been a source of medical agents for several years, and this of using plants for prevention and treatment of various diseases had existed since time immemorial. It is estimated that about $25 \%$ of orthodox drugs prescribed are derived from plants. In recent times, medicinal plants which are previously with unknown pharmacological or therapeutic activities had been investigated extensively as a potential source of medicinal agents. For instance, substances derived from the plants remain the basis for a large proportion for the treatment of malaria fever, heart diseases, elevated blood pressure, pain, asthma, arthritis among other health related problems. This is due to the fact that, plants contain variety of biological active constituents that act upon diseased tissues or organs in the body and effect therapeutic outcomes. 
Medicinal plants in Nigeria and other African countries have been prepared into various forms for use by humans. This tradition has gained global recognition from both developed and developing nations for many years. Plants can be prepared into liquid forms, paste, ointment, tinctures, creams or even solid forms as tablets (Kamal et al., 2012). Despite the merits derived from the use of medicinal plants for the treatment of diseases, these are without basic scientific justifications to validly back claims of lack of side effects. This neglected essential aspect of drug formulation is very dangerous, and has resulted in many side effects and deaths to its users in health care system especially in Nigeria (Miruts et al., 2013; Bhushan et al., 2014). Medicinal plants contain many phytochemicals which are complex both chemically and structurally. Some of these chemical constituents such as alkaloids, saponins, and cyanogenic glycosides has been reported to have caused various degree of damage to vital organs in the body if taken over-dosed. It is then necessary to validate scientifically the safety of all medicinal plants as well as their products using approved standard toxicological protocols (Ukwubile et al., 2019; Aneela et al., 2011; Rahman et al., 2014) This type of study will make a conclusion on whether a medicinal plant or its products should be consumed or use for health related cases, or otherwise (Aneela et al., 2011). Evaluating the toxic profiles of medicinal plants will reveal some toxicological indices of such plant. For instance the plant may be toxic, moderately toxic, or non-toxic. It will further reveal the dose levels of safety and toxic, and this findings will guide traditional medicine practitioners or beverage industries and companies during the manufacturing processes of herbal products. Besides, this aspect of ethnopharmacological research is valid scientifically, and it is a mandatory requirement before any new herbal products is given to humans for use, in order to prevent toxicity effects arising from longterm use of herbal products (Robinson et al., 2009).

\subsection{Camellia sinensis from Mambila beverages Ltd Nigeria and its distribution}

The Nigerian traditional medicine systems made use of large number of herbs, parts of shrubs and trees from different plant families and species as well as animal parts (Ezeja et al., 2014; Sofowora, 2006). Among the plants used in treatment of diseases in Mambila plateau located in Nigerian's north-eastern region State Taraba is Camellia sinensis from where green tea is made by this beverage industry Mambila beverages Nig. Ltd.

Camellia sinensis belongs to the family Theaceae (the tea family) with about 450 species and more than 50 genera among angiosperms consisting of trees and shrubs, rarely lianas (Burkill, 1997; Hutchings, 1996). The leaf is notably used as green tea in Nigeria, and its sale as green tea by this industry y has generated huge income to the Taraba State government, Nigeria (the owner of the industry). The bark decoction is used as remedy for malaria and typhoid fevers by Nguroje people in Mambila plateau. The leaf extract had been reported as potential anti-oxidant and potent remedy for cancers in traditional medicine due to the presence of some secondary metabolites such as flavonoids, alkaloids and terpenoids in the leaf extract (Chan et al., 2007; Ukwubile et al., 2018). Its anti-carcinogenic, antibacterial, anti-diabetic, anti-tumor and anti-hypertensive activities has also been reported (Wang and Ren, 2002; Florence et al., 2010; Chan et al., 2007). It is native to the Caribbean, Cuba, Jamaica, Trinidad and Tobago, Dominican Republic, Haiti, Puerto Rico, Barbados; North America: Mexico; Central Africa; Costa-Rica, El Salvador, Guatemala, Honduras, Nicaragua, Panama, Belize; parts of other Africans like Republic of Congo, Ghana, Madagascar, and Nigeria (Ukwubile et al., 2018). In Nigeria, it is found only in Mambila plateau, Sarduana Local Government, Taraba State ${ }^{15}$, where it grows well in cold climate and temperature range of 5 to $7^{\circ} \mathrm{C}$.

Despite the popular roles of the leaf of the plant in health care delivery in Nigeria, the detailed phytocomposition screening of the leaves in different solvents, and its safety profiles were not fully or evaluated at all. Hence, the need for this present study.

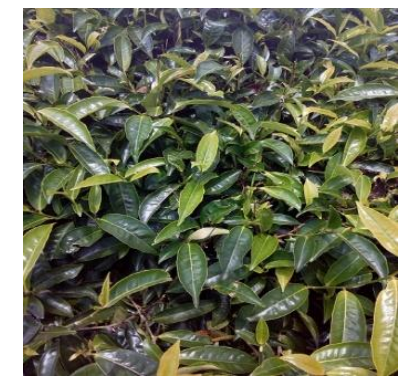

Fig1. Pictorial view of Camellia sinensis in its natural habitat (Ukwubile et al., 2018). 


\section{Materials AND Methods}

\subsection{Reagents and Apparatus used}

$\mathrm{N}$-hexane, carbon tetra chloride (CCL4), chloroform(CCl3), ethyl acetate, acetone, methanol, and ethanol (from Sigma Aldrich, USA), phytochemical reagents, haematoxylin \& eosin stains, $10 \%$ formalin dissecting kits, liver function and lipid profiles kits, mindray BC-2800 auto haematology analyzer, Roche reflotron plus auto analyzer, compound microscope, etc.

\subsection{Collection and Identification of Plant}

Fresh leaves of $C$. sinensis were collected from Mambila beverages Ltd in Taraba State in the evening hours (6-7 pm), and was identified by a taxonomist at Department of Biological Sciences, Taraba State University, Jalingo, where a voucher specimen was deposited for the plant. They were air-dried for two weeks under shades and pulverized into fine powder.

\subsection{Extraction of Plant Materials}

The fine powdered leaves weighing $1.2 \mathrm{Kg}(1200 \mathrm{~g})$ was extracted in 2.5 litres methanol using cold maceration technique for $48 \mathrm{~h}$. The extract was then filtered using Whatman № 1 filter papers into clean beakers. Methanol extract of leaf was then subjected to liquid-liquid partition (LLP) using solvents in increasing order of polarity from n-hexane, carbon tetra chloride, chloroform, acetone, ethyl acetate, methanol, ethanol and aqueous. The filtrates from each fraction were then concentrated in vacuo using rotary evaporator at room temperature. The final weight of each extract was noted, and the extracts were labelled accordingly and then stored in refrigerator at $-4^{\circ} \mathrm{C}$ for further use.

\subsection{Preliminary Phytochemical of C. Sinensis Leaf Extract}

Chemical tests were carried out on the extracts of Camellia sinensis using standard procedures to identify the constituents as described by Evans (2009), Sofowora (2006) and Ukwubile et al. (2018), were adopted to test for the presence of some major plant constituents or phytocomposition in the leaf extract. A brief description of the methods are as follows:

\subsubsection{Test of Carbohydrates}

Molisch test: $0.5 \mathrm{~g}$ of the extracts were placed in a test tube, few drops of Molisch reagent was added and concentrated sulphuric acid was added down the side of the test tube to form a lower layer, a reddish coloured ring at the interphase indicates presence of carbohydrates.

Fehling's test: To $0.5 \mathrm{~g}$ portion of the extracts in test tubes, $5 \mathrm{~mL}$ of an equal mixture of Fehling solution A and B was added and boiled on a water bath, brick red precipitate indicates presence of reducing sugar.

\subsubsection{General Test for Glycosides}

To $0.5 \mathrm{~g}$ of the extracts $5 \mathrm{~mL}$ of dilute sulphuric acid was added and boiled on a water bath for $10 \mathrm{~min}$. It was cooled and neutralized with $20 \% \mathrm{KOH}$. It was then divided into two portions. To the first portion, $5 \mathrm{~mL}$ of a mixture of Fehling's solution A and B were added and boiled. A brick red precipitate showed the release of reducing sugar as a result of hydrolysis of glycosides. To the second portion, about $3 \mathrm{~mL}$ of ferric chloride solution was added. A green to blue colour was produced because phenolic aglycones were released due to the hydrolysis.

\subsubsection{Test for Free Anthracene Derivatives}

Borntrager's test: To $0.5 \mathrm{~g}$ of the extracts in dry test tubes, $5 \mathrm{~mL}$ of chloroform was added and shaken for $5 \mathrm{~min}$. It was filtered, and the filtrate was then shaken with equal volume of $10 \%$ ammonia solution. A pale pinkish colouration in the aqueous phase showed the presence of free anthracene in the solution (Evans, 2009).

\subsubsection{Test for Unsaturated Steroid and Triterpenes}

Liebermann-Bucchard's test: To $0.5 \mathrm{~g}$ of the extracts, equal volume of acetic acid anhydride was added, and mixed gently. $1 \mathrm{~mL}$ of concentrated sulphuric acid was added down the side of the test tube to form a lower layer. Colour changes were observed immediately, and over a period of one hour. Blue to bluegreen colour in the upper layer and a reddish to pink or purple colour indicate the presence of triterpenes. 


\subsubsection{Test for Cardiac Glycosides}

Keller-Kiliani's test: $0.5 \mathrm{~g}$ extracts were dissolved in $1 \mathrm{~mL}$ glacial acetic acid containing traces of ferric chloride solution. This was then transferred into a dry test tube. After this, $1 \mathrm{~mL}$ concentrated sulphuric acid was added down the side of the tube to form a lower layer at the bottom, and observed carefully at the interphase for purple-brown ring formation. This indicates the presence of deoxy sugars. A pale green colour in the upper acetic acid layer indicates the presence of cardiac glycosides (Evans, 2009; Sofowora, 2006).

Kedde's test: To $0.5 \mathrm{~g}$ extracts, $1 \mathrm{~mL}$ of $2 \%$ solution of 3, 5-Dinitrobenzoic acid was added in $95 \%$ $(\mathrm{v} / \mathrm{v})$ alcohol. The solution was made alkaline by adding $5 \%$ sodium hydroxide solution. Appearance of purple-blue colouration, indicates the presence of cardenolides.

\subsubsection{Test for Saponins Glycosides}

Frothing test: About $10 \mathrm{~mL}$ of distilled water was added to $0.5 \mathrm{~g}$ leaf extracts, and was shaken vigorously for $30 \mathrm{sec}$. The tube was allowed to stand in a vertical position and observed for $30 \mathrm{~min}$. A honeycomb froth that persisted for 15 min indicates presence of saponins.

\subsubsection{Test for Tannins}

Ferric chloride test: To $0.5 \mathrm{~g}$ of leaf extracts, 3 drops of ferric chloride solution were added. A greenishblack precipitate indicates the presence of tannins.

Lead sub-acetate test: To $0.5 \mathrm{~g}$ each of the extracts, 3 drops of lead sub-acetate solution were added. Coloured precipitate in the solutions indicate the presence of tannins.

\subsubsection{Test of Flavonoids}

Shinoda's test: A small portion of each extract was dissolved $2 \mathrm{~mL}$ of $50 \%$ methanol in heat metallic magnesium chips. Few drops of concentrated hydrochloric acid were then added. Appearance of red colouration in solution indicates the presence of flavonoids.

Sodium hydroxide test: Few drops of $10 \%$ sodium hydroxide were added to the extracts. The formation of yellow coloration indicates presence of flavonoids.

Ferric chloride test: Few drops of ferric chloride solution were added to a portion of the extract, a green precipitate indicates presence of phenolic group.

\subsubsection{Test for Alkaloids}

Dragendorff's test: To small portions of the extracts, few drops of Dragendorff's reagent were added. Formation of reddish-brown precipitate indicates presence of alkaloids.

Picric acid test: Few drops of $1 \% \mathrm{v} / \mathrm{v}$ picric acid solution were added to small portions of the extract in test tubes. The formation of yellow coloration indicates presence of alkaloids in the solutions.

Wagner's test: Few drops of Wagner's reagent were added to portions of the extracts dissolved in $5 \mathrm{~mL}$ distilled water. The formation of whitish precipitate indicates presence of alkaloids.

\subsection{Experimental Design for Acute Toxicity Assessment C. Sinensis Leaf Extract}

\subsubsection{Experimental Animals}

Thirty Swiss albino mice of opposite sexes weighing 15-22 $\mathrm{g}$ were obtained from the animal houses of the Department of Pharmacology, University of Jos, Nigeria. The animals were housed in stainless steel cages, and supplied with clean drinking water, and fed with food (ad libitum) with standard animal commercial feed (Royal Feeds, Nigeria Ltd) in an environment of ambient temperature $\left(26{ }^{\circ} \mathrm{C}\right)$ and lighting period of $12 \mathrm{~h}$ per day, with relative humidity of $60 \%$. The animals were allowed to acclimatize to the laboratory where the study will take place for 1 week. The experimental procedures for this study were approved by research ethical committee of the above mentioned university, and their guidelines were strictly adhered to. The volume of extract used was calculated from the formula below:

Volume of the extract $(\mathrm{mL})=\frac{\text { weight of mice }(\mathrm{kg}) \times \text { dose rate }(\mathrm{mg} / \mathrm{kg})}{\text { extract concentration }(\mathrm{mg} / \mathrm{mL})}$

where, stock concentration $=$ dose rate $(\mathrm{mg} / \mathrm{kg}) / 10$ (for mice) (Ukwubile et al., 2018).

\subsubsection{Acute Toxicity Study of Extract}

Acute toxicity $\left(\mathrm{LD}_{50}\right)$ study was carried out in accordance with Organization for Economic Cooperation and Development (OECD) guide lines paragraph 453 (OECD, 2009). Three Swiss albino mice of 
opposite sexes were weighed and fasted overnight. Test dose of the plant extract was calculated with respect to animal's body weights. A limit test dose of $2000 \mathrm{mg} / \mathrm{kg}$ b.w. were administered to the animals via oral gavages. After this, the animals were regularly observed for behavioural changes and general toxicity signs such as restless, hypoactive, itching and reddish eyes, as well as death especially within the first $4 \mathrm{~h}$ of administration and for $24 \mathrm{~h}$. Observations were then continued on daily basis for 14 days with free access to water and food (Bello et al., 2016; Kumar, 2019).

\subsubsection{Subchronic Toxicity Study of C. Sinensis Leaf Extract}

Thirty (30) Swiss albino mice comprising twenty males and ten females were allowed to acclimatized in the laboratory for I week. The animals were then weighed on a scale balance, and divided into five groups of six each with two females per group. They were kept in separate cages and labelled accordingly. Mice in group I which served as the normal control group were administered $10 \mathrm{~mL}$ distilled water throughout the study period while those in groups II, III,IV, and V were orally administered doses of 300,600, 900 and $1200 \mathrm{mg} / \mathrm{kg}$ b.w. leaf extract orally (p.o) respectively, once daily for 28 days. The body weights of the mice were recorded thrice per week throughout the experimental period. After 28 days of treatment, the mice were fasted for 8 hours and gently anaesthetized using chloroform. Blood samples were immediately collected into EDTA bottles by cardiac puncturing for blood and biochemical parameters (Bello et al., 2016; Saidu et al., 2010; Mbaka et al., 2010; Mukinda and Syce, 2007).

\subsubsection{Determination of Weight of Vital Organs in Mice}

After 28 days, the animals were sacrificed under chloroform anaesthesia, and the weights of some vital organs such as the liver, kidney, heart, lung, ovary and testis were measured by dissecting carefully each organ from the sacrificed mice into $10 \%(\mathrm{v} / \mathrm{v})$ formalin in a clean Petri dish. Water was drained from the organs using cotton wool, and thereafter weighed on an electronic micro scale balance. Three replicate readings were taken and the average was taken as the weight of the organs (Bello et al. 2016).

\subsubsection{Determination of Blood Parameters}

Blood parameters such as white blood cell (WBC) count, differential WBC data, platelets, red blood cell (RBC) count, leukocyte counts, red cell distribution width (RDW), platelet count, haemoglobin estimation count $(\mathrm{Hb})$, packed cell volume $(\mathrm{PCV})$, mean cell volume (MCV), mean corpuscular haemoglobin $(\mathrm{MCH})$ and mean corpuscular haemoglobin concentration $(\mathrm{MCHC})$ were analysed using mindray BC-2800 auto haematology analyzer at $37^{\circ} \mathrm{C}$ and normal atmospheric pressure. Whole blood were collected from the rats by cardiac puncturing and stored in separate EDTA bottles for these analysis. The values for each parameters were auto-printed by the apparatus (Ukwubile et al., 2019).

\subsubsection{Determination of Serum Biochemical Parameters}

Biochemical parameters were analysed using Reflotron ${ }^{\circledR}$ Plus (Roche, Germany) auto-analyzer with various kits at $37^{\circ} \mathrm{C}$. These are:

Liver function: aspartate aminotransferase (AST), alanine aminotransferase (ALT), alkaline phosphatase (ALP), total serum protein, direct and indirect bilirubin, total bilirubin, and serum albumin (ALB).

Lipid profiles: total cholesterol, triglycerides, high density lipoproteins (HDL), low density lipoprotein (LDL), and very low density cholesterol (VLDL).

Kidney function: serum urea, uric acids, serum creatinine, plasma glucose, sodium ion, chloride ion, calcium ions, magnesium ions, potassium ion and phosphate ions.

In determining these parameters, whole blood which were collected from the mice were centrifuged at $3000 \mathrm{rpm}$ for $15 \mathrm{~min}$ to obtain clear serum. Plasma glucose was analysed using the plasma content of the blood using mindray auto haematology apparatus.

\subsubsection{Histopathological Examination of Vital Organs of Mice}

Examination of organs such as the liver, kidney, heart, lung, pancreas, testes and ovary of the animals from each group were carried out by fixing the tissues in $10 \%$ formalin solution. The organs were then partially dehydrated, and a thin section of the organs were on clean slides. Tissue of the organs were then stain with haematoxylin and eosin stain, and viewed using microscope (Kumar, 2019).

\subsection{Statistical Analysis}

Data obtained from the study were subjected to one-way analysis of variance (one-way ANOVA) and differences between mean were determined by Turkey's multiple comparison test analysed by statistics 
software SPSS (version 23) to compare the significance difference between treated and control groups at $\mathrm{p} \leq 0.05$.

\section{Results}

\subsection{Phytochemical Screening of Leaf Extracts}

Preliminary phytochemical screening of leaf extracts (Table 1) in various solvents revealed the presence of major metabolites in ethyl acetate portion than other portions. Saponins were not detected in all the fractions while alkaloids were detected in the non polar and ethyl acetate portions.

Table1. Preliminary Phytochemical Screening of Methanol Extracts of C. sinensis

\begin{tabular}{|c|c|c|c|c|c|c|c|c|c|}
\hline \multirow[t]{2}{*}{ Constituent } & \multirow[t]{2}{*}{ Test } & \multicolumn{6}{|c|}{ Extract fractions } & \multirow[b]{2}{*}{ Eth } & \multirow[b]{2}{*}{ Aqu } \\
\hline & & $\mathrm{nH}$ & CCL4 & $\mathrm{CCL}_{3}$ & Actn & EAc & Met & & \\
\hline \multirow[t]{2}{*}{ Carbohydrates } & Molisch & - & - & - & - & 4 & + & + & + \\
\hline & Fehling's & - & - & - & - & + & + & + & + \\
\hline Anthraquinones & Borntragers & - & - & - & - & + & + & ++ & + \\
\hline Tripenes & Liebcrmann & - & - & - & - & ++ & ++ & - & - \\
\hline Cardiac glyc & Keller-Kiliani & - & - & - & + & + & + & + & + \\
\hline Saponins & Frothing & - & - & - & - & - & - & - & - \\
\hline \multirow[t]{2}{*}{ Tannins } & $\mathrm{FeCl}_{3}$ & - & - & - & - & - & - & - & - \\
\hline & Lead Act & - & - & +1 & + & $+t$ & - & - & + \\
\hline \multirow[t]{2}{*}{ Flavonoids } & Shinoda & - & - & + & + & ++ & ++ & + & +1 \\
\hline & $\mathrm{NaOH}$ & - & - & - & + & ++ & + & + & + \\
\hline \multirow[t]{3}{*}{ Alkaloids } & Dragendorff's & + & + & +1 & + & $+t$ & - & - & - \\
\hline & Picric acid & + & + & + & - & + & + & + & - \\
\hline & Wagner & + & - & + & + & ++ & - & - & - \\
\hline
\end{tabular}

Note: ++ (detected in large amount), + (detected in trace amount), - (not detected), $\mathrm{nH}$ (n-hexane), $\mathrm{CCl}_{4}$ (carbon tetrachloride), $\mathrm{CCl}_{3}$ (chloroform), Actn (acetone), EAc (ethyl acetate), Met (methanol), Eth (ethanol), Aqu (aqueous), Lead Act (Lead sub acetate).

\subsection{Acute Toxicity Study of C. Sinensis Leaf Extract}

From the result obtained, none of the animal suffered any obvious pathological damage or death after $24 \mathrm{~h}$ acute intoxication of extract at $2000 \mathrm{mg} / \mathrm{kg}$ b.w. Behavioural changes such redness of eyes, itching, restiveness, and hypo activity such as low food and water intake were witnessed in mice in the first 4 $\mathrm{h}$. These toxic signs later disappeared within $24 \mathrm{~h}$. There were no mortality recorded in any group after 14 days; implying the animals tolerated the extract at the dose level, and all the animals had $100 \%$ survival rate from acute intoxication as shown in Fig. 2 below.

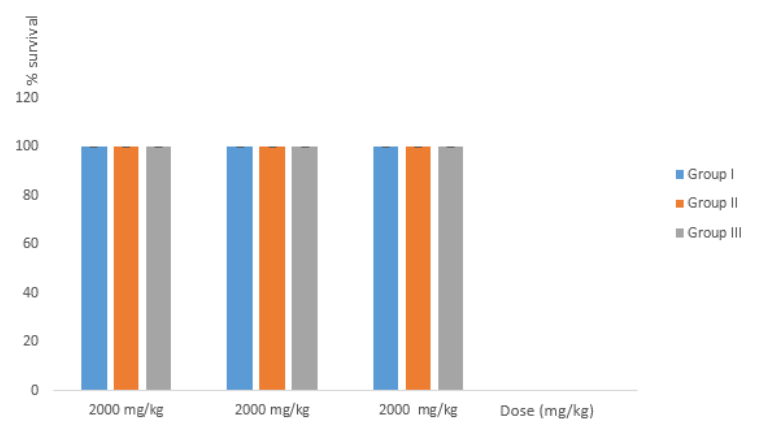

Fig2. Acute toxicity of C. sinensis leaf methanol extract at $2000 \mathrm{mg} / \mathrm{kg}$ b.w. after 14 days.

\subsection{Change in Body Weight of Mice After 28 Days Administration of Extract Doses}

There were no significance change in body from week one to week four in treated and control group as shown in Figure 3 below: 


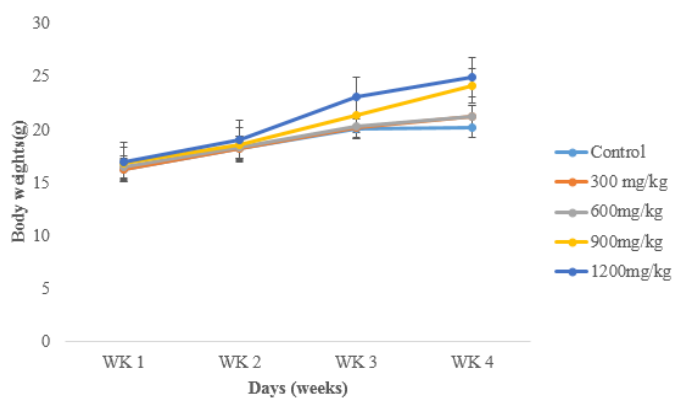

Fig3. Body weight changes after regular doses of C. sinensis leaf extract for 28 days.

Values are represented as mean $\pm S D, n=5$ mice per group.

\subsection{Changes in Weight of Vital Organs After 28 Days of Oral Administration}

Slight increase in weights of organs were witnessed in the kidney, lung, ovary and testis at higher doses of 900 and $1200 \mathrm{mg} / \mathrm{kg}$. These increases were not different significantly from that of the control group ( $\mathrm{p} \leq 0.05$; one-way ANOVA) (Table 2).

Table2. Relative organ weights of mice dosed with $C$. sinensis leaf extract for 28 days

\begin{tabular}{llllll} 
Organ & Contro1 & \multicolumn{5}{c}{ Camellia sinensis extract (mg/kg) } \\
\hline Kidney & $0.50 \pm 0.01$ & $0.52 \pm 0.02$ & $0.50 \pm 0.01$ & $0.49 \pm 0.02$ & $0.54 \pm 0.01$ \\
Liver & $1.62 \pm 0.01$ & $1.68 \pm 0.10$ & $1.69 \pm 0.01$ & $1.74 \pm 0.04$ & $1.77 \pm 0.02$ \\
Heart & $0.22 \pm 0.02$ & $0.20 \pm 0.01$ & $0.18 \pm 0.04$ & $0.17 \pm 0.02$ & $0.21 \pm 0.01$ \\
Lung & $0.65 \pm 0.02$ & $0.68 \pm 0.02$ & $0.66 \pm 0.12$ & $0.62 \pm 0.10$ & $0.67 \pm 0.02$ \\
Spleen & $0.11 \pm 0.01$ & $0.14 \pm 0.01$ & $0.12 \pm 0.02$ & $0.08 \pm 0.01$ & $0.04 \pm 0.01$ \\
Ovary & $0.32 \pm 0.05$ & $0.51 \pm 0.01$ & $0.50 \pm 0.02$ & $0.51 \pm 0.01$ & $0.48 \pm 0.02$ \\
Testis & $0.45 \pm 0.04$ & $0.47 \pm 0.03$ & $0.46 \pm 0.12$ & $0.48 \pm 0.02$ & $0.49 \pm 0.01$ \\
\hline
\end{tabular}

Note data are presented as the mean $\pm \mathrm{SD}$ ( $\mathrm{n}=6$ mice per group), relative organ weights were calculated as [organ weight/body weight] 100, and $\mathrm{p} \leq 0.05$ (one-way ANOVA).

\subsection{Blood Profiles of Mice After 28 Days of C. Sinensis Leaf Extract Administered Orally}

Continuous administering of leaf extract doses to the mice for 28 days results in significant decrease in $\mathrm{RBC}$, and $\mathrm{Hb}$ whereas $\mathrm{WBC}$, and other blood parameters showed significance increase in dosedependent fashion. The values obtained from this study were not significantly different from that of the control group ( $\mathrm{p} \leq 0.05$; one-way ANOVA). Results from the haematological parameters were recorded in Table 3 below:

Table3. Effects of C. sinensis leaf extract on blood parameters of mice after 28 days oral subchronic toxicity study

\begin{tabular}{|c|c|c|c|c|c|}
\hline \multirow[t]{2}{*}{ Parameter } & \multirow[t]{2}{*}{ Control } & \multicolumn{4}{|c|}{ Camellia sinensis extract $(\mathrm{mg} / \mathrm{kg})$} \\
\hline & & 300 & 600 & 900 & 1200 \\
\hline $\mathrm{Hb}(\mathrm{g} / \mathrm{L})$ & $11.50=0.41$ & $11.60=0.40$ & $14.10=0.10$ & $12.08=0.04$ & $12.14=0.40$ \\
\hline $\mathrm{RBC}\left(1 \mathrm{O}^{12} / \mathrm{L}\right)$ & $6.80 \pm 0.04$ & $8.32 \pm 0.01$ & $9.17 \pm 0.02$ & $9.04 \pm 0.02$ & $7.24 \pm 0.01$ \\
\hline $\mathrm{PCV}(\%)$ & $39.91=0.48$ & $42.08 \pm 0.16$ & $45.13 \pm 0.42$ & $48.00=0.42$ & $48.05 \pm 0.11$ \\
\hline MCV (fI) & $62.15 \pm 0.56$ & $58.18=0.32$ & $60.01 \pm 0.18$ & $56.25 \pm 0.12$ & $45.88=0.12$ \\
\hline MCHC $(g / L)$ & $24.05 \pm 0.14$ & $26.24=0.01$ & $28.11=0.15$ & $28.42 \pm 0.13$ & $30.12 \pm 0.16$ \\
\hline MCH (pg) & $18.12 \pm 0.25$ & $18.68=0.21$ & $22.00=0.14$ & $18.61=0.20$ & $16.01=0.10$ \\
\hline $\mathrm{WBC}\left(10^{9} / \mathrm{L}\right)$ & $24.32=0.10$ & $26.17=0.28$ & $26.66=0.18$ & $28.59=0.14$ & $32.21=0.12$ \\
\hline$\%$ Neutrophils & $1.18 \pm 0.02$ & $1.88 \pm 0.01$ & $1.92 \pm 0.02$ & $2.01 \pm 0.01$ & $2.50 \pm 0.01$ \\
\hline$\%$ Lymphocyte & $5.08 \pm 0.42$ & $5.88 \pm 0.20$ & $6.12 \pm 0.05$ & $6.78 \pm 0.01$ & $6.89 \pm 0.04$ \\
\hline$\%$ Basophiles & $0.02 \pm 0.00$ & $0.01 \pm 0.01$ & $0.02 \pm 0.01$ & $0.01 \pm 0.01$ & $0.02 \pm 0.00$ \\
\hline$\%$ Eosinophil & $0.05 \pm 0.01$ & $0.03 \pm 0.01$ & $0.04 \pm 0.02$ & $0.05 \pm 0.01$ & $0.07 \pm 0.03$ \\
\hline$\%$ Monocytes & $0.03 \pm 0.01$ & $0.03 \pm 0.01$ & $0.02 \pm 0.00$ & $0.30 \pm 0.01$ & $0.03 \pm 0.01$ \\
\hline Platelets $\left(10^{\rho / L}\right)$ & $76.26 \pm 0.32$ & $89.21=5.20$ & $92.10 \pm 6.14$ & $92.88=8.04$ & $98.34=6.12$ \\
\hline$\%$ RDW & $15.10 \pm 1.16$ & $15.88=1.12$ & $17.02 \pm 1.08$ & $17.88=4.51$ & $18.50=3.20$ \\
\hline PDW (fI) & $28.01=2.01$ & $28.76 \pm 1.02$ & $28.88=1.02$ & $32.13 \pm 4.20$ & $34.11=6.01$ \\
\hline
\end{tabular}

Note: results are mean \pm SD of six rats in each group, $p \leq 0.05$ (one-way ANOVA). RBC (red blood cells), $\mathrm{Hb}$ (haemoglobin count), MCV (mean corpuscular volume), MCH (mean corpuscular haemoglobin), MCHC (mean corpuscular haemoglobin concentration), PLT (platelets), WBC (white 
blood cells), PCV (packed cell volume), RDW (red blood cell distribution width), PDW (platelet distribution width).

\subsection{Serum Biochemical Parameters of Mice After 28 Days Oral Administration of C. Sinensis Leaf Extract}

Alkaline phosphatase (ALP) levels decreases from doses of $300 \mathrm{mg} / \mathrm{kg}$ to $900 \mathrm{mg} / \mathrm{kg} \mathrm{b.w}$. but increased slightly at $1200 \mathrm{mg} / \mathrm{kg}$ b.w. of extract in the animals. However, other biochemical parameters such as alanine transaminase (ALT), aspartate transaminase (AST), total proteins (TP), bilirubin, albumin, and globulins maintained steady increase as the doses increased. See Fig. 4 below:

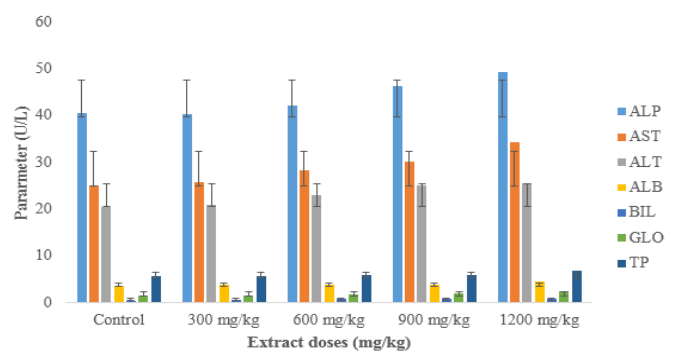

Fig4. Serum biochemical profiles of mice at different doses after 28 days oral administration of C. sinensis extract; mean $\pm S D$ ( $n=6$ mice per group). ALP (alkaline phosphatase), AST (aspartate transaminase), ALT (alanine transaminase), ALB (albumin), BIL (bilirubin), GLO (globulins), TP (total proteins).

\subsection{Serum Electrolytes Profile of Mice Administered C. Sinensis Extract Orally for 28 Days}

From the results obtained, serum sodium ions $\left(\mathrm{Na}^{+}\right)$, potassium ions $\left(\mathrm{K}^{+}\right)$, and chloride ions $\left(\mathrm{Cl}^{-}\right)$showed significant increase in dose dependent fashion. It was however, noticed that at highest dose of 1200 $\mathrm{mg} / \mathrm{kg}$ b.w. extract, biochemical parameters such as urea, phosphate, and uric acid decreased in value while increase in values was witnessed in creatinine and calcium ions $\left(\mathrm{Ca}^{2+}\right)$. Values obtained were presented in the Fig. 5 below:

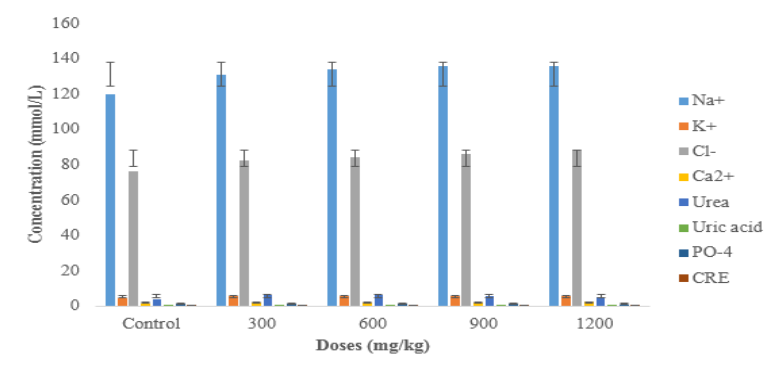

Fig5. Effect of $C$. sinensis leaf extract on serum electrolytes of mice after 28 days oral administration; mean $\pm S D$, $n=6$ mice per group.

\subsection{Lipid Profiles and Plasma Glucose of Mice After 28 Days Toxicity Study}

Subchronic dosing of $C$. sinensis leaf extract to Swiss albino mice after 28 days orally, increased all the serum lipid profiles and plasma glucose in dose dependent fashion except low density lipoproteins (LDL) whose values decreased with increased doses of extract. The Fig. 6 below showed that there were significant difference in LDL when compared with the control at $p \leq 0.05$.

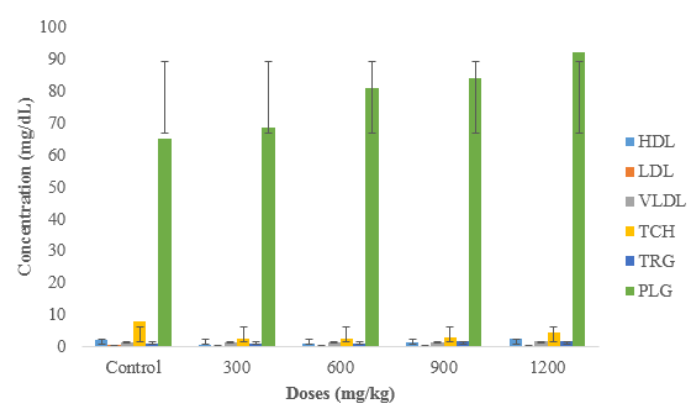

Fig6. Effects of C. sinensis leaf extract doses on serum lipid profiles and plasma glucose level of mice after 28 days. 


\subsection{Histopathological Examination of Organs of Mice Administered C. Sinensis Leaf Extract After 28 Days Orally}

No pathological defects were witnessed in the liver, kidney, lung and testis of mice treated with various extract doses after 28 days. Venial or capillary blood congestions were not noticed when examined under the microscope. See Fig. 7 below:
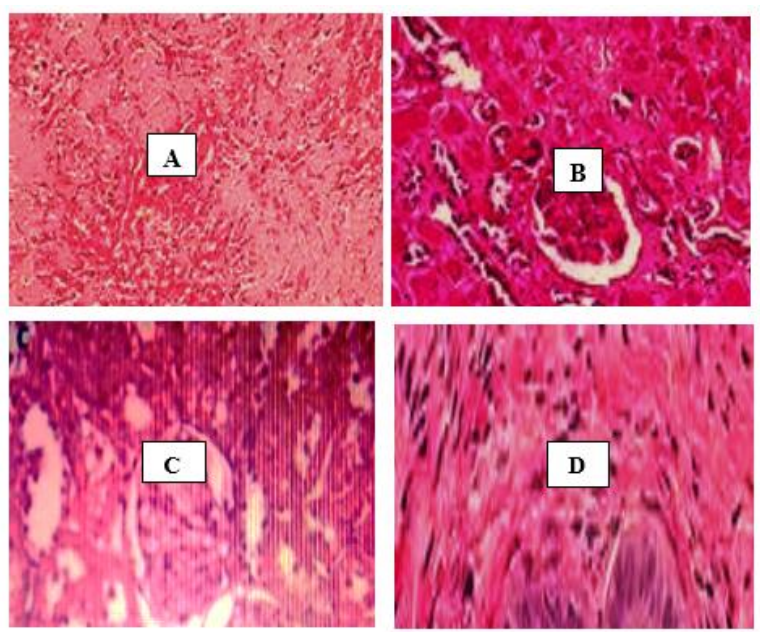

Fig7. Photomicrographs of sections of: A (liver), B (kidney), C (lung) and D (testis) of mice administered with $1200 \mathrm{mg} / \mathrm{kg} \mathrm{b.w.} \mathrm{extract} \mathrm{doses} \mathrm{of} \mathrm{C.} \mathrm{sinensis} \mathrm{after} 28$ days. No significance different from control group; $p \leq 0.05$.

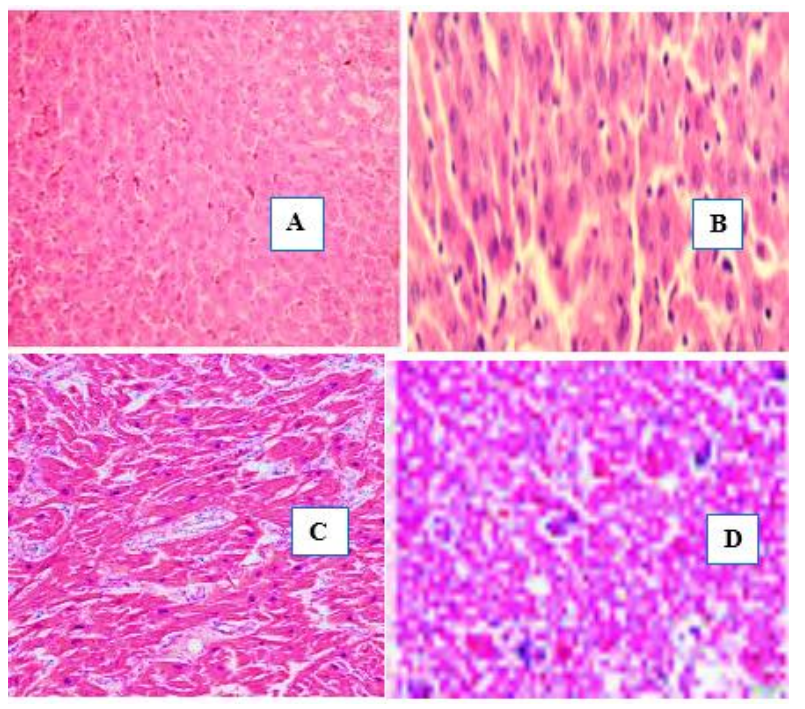

Fig8. Photomicrographs of sections of: $\boldsymbol{A}$ (liver), $\boldsymbol{B}$ (kidney), $\boldsymbol{C}$ (lung) and $\boldsymbol{D}$ (testis) of control mice group administered with distilled water after 28 days. No significance different from the treated groups; $p \leq 0.05$.

\section{DISCUSSION}

The use of herbal preparations dated for centuries. This interest in the use herbal products for managing and treating ailments become popular in most developed countries not too long ago, especially with the passage of the Dietary Supplement Health and Education Act in 60s in the US. Currently, there exist many regulatory agencies for herbal products in many countries. For examples, the food and drug administration (FDA) in the USA, the national agency for food drug administration and control (NAFDAC) in Nigeria, and others ensured that herbs and herbal products meet the standards before being approved for use for health care purposes.

However, despite the popularization of herbs and herbal products, information about their safety and efficacy is not sufficient globally as compared to those of convectional drugs. Herbal preparation from Camellia sinensis leaf (green tea) is one the major source income to the government of Taraba State, Nigeria; marketed by Mambila Beverages Ltd. Green tea produced from C. sinensis has gained global recognition in Nigeria and some African countries for acclaimed antioxidant activities of the leaves. In this study phytochemical constituents of the leaf were evaluated in various solvents of varying 
polarities. The result revealed the presence of carbohydrates, anthracenes, cardiac glycosides, flavonoids, triterpenes and alkaloids in the ethyl acetate fraction while saponins and tannins were not detected in of the fractions (Table 1). Phytoconstituents of plants are responsible for their biological activities such as anticancer, antimalarial, antihypertensive, analgesics, anticonvulsive, cardiac stimulants, immune stimulants, hepatoprotective and antiulcer (Mbaka et al., 2010; Thapa and Walla, 2007). For instance, carbohydrates serve as energy reserves, fuels, and metabolic intermediates in living tissues, and are stored as glycogen in animals and starch in plants for their daily processes. They also form protective and structural components of many organisms like insects, plant cell wall and bacterial cell wall (Evans, 2009; Iwu, 1993). These roles were not different from that which it carries out in this present study especially for those who consumed $C$. sinensis preparations as green tea.

Flavonoids have been reported to possessed antioxidant and anticancer activities in humans. It is not surprising, therefore, as to why $C$. sinensis leaf was reported to have strong antioxidant in DPPH radical scavenging ability, ferric-reducing antioxidant power, and ferrous-ion chelating ability (Chan et al., 2007), and anticancer activities against MCF-7 breast cancer cell line. Various class of alkaloids were also known to possess antimalarial, anticancer, antimicrobial, correction of renal problems, antihistamine, among other activities. For examples, codeine is used in non-addictive way as powerful analgesic, quinine is used to correct irregular heartbeat, ergonovine is used to control bleeding after child birth, etc. The presence of alkaloids in ethyl acetate fraction revealed that the leaf extract of $C$. sinensis could also be beneficial as agent against malaria, cancer, and microbial infections as well as the aforementioned. The increase use of $C$. sinensis as green tea in Nigeria and other African countries was due to the numerous health benefits above.

However, the use of preparations from C. sinensis leaf in most cases were without prescribed dosages, hence, this study also investigated the effects of short term (acute) and long term (subchronic) usage (intake) orally in mice. Acute toxicity study by Ukwubile et al. (2018), showed that the plant had $\mathrm{LD}_{50}$ $\geq 5000 \mathrm{mg} / \mathrm{kg}$ b.w. in Swiss albino mice but reduced metabolic activities such weakness, itching and food intake as well as reddish eyes were noticed at dose $5000 \mathrm{mg} / \mathrm{kg}$ b.w which lasted for few minutes. In this present study, administering of $2000 \mathrm{mg} / \mathrm{kg}$ b.w. to the mice orally produced similar signs in first 24 hours, and the animals resumed normal activities after this period. No death was witnessed (Fig.2). After 28 days of subchronic study, there was slight increase in weights in the mice in dose-dependent manner. These increases may be due hypertrophy of organs such as the liver (table 2; figs. 3, 7 and 8). Similarly, hypertrophy in the heart is usually a chronic hemodynamic overload, which from either hypertension or faulty valves. This is due to morbid increase in blood quantity in these organs, which might be similar in this study. Ukwubile et al (2018), reported weight decrease mice as the dose increases. In this study, only the spleen and ovary showed decrease in weight (hypotrophy) at 2000 $\mathrm{mg} / \mathrm{kg} \mathrm{b.w}$. in the mice. These weight decrease were not statistically significantly difference from the control ( $\mathrm{p} \leq 0.05$; one-way ANOVA).

The knowledge of side effects of any drug being it conventional or traditional herbs is very crucial to grantee the safety of such drug in humans (Thierry et al., 2011; Mukinda and Syce, 2006; Olorunnisola et al., 2012). Toxicology is defined as the science of poisons. It expands our understanding of how various drugs can cause harm to tissues of the body. It can said also that this science studies the adverse effects of chemicals or physical agents or drugs on living organisms. In this present study, subchronic toxicological assessments were carried out in order to determine any effects which are deleterious resulting from prolong use of $C$. sinensis oral intake. Results in table 3 showed that blood indices such as $\mathrm{RBC}, \mathrm{Hb}, \mathrm{MCH}$ and $\mathrm{MCV}$ decreased slightly (a condition referred to as microcytic hypochromic anaemia) but these reductions fall within the acceptable range. Because, it has been reported that, when the $\mathrm{RBC}$ size is reduced below the range, the $\mathrm{Hb}$ content of the $\mathrm{RBC}$ also reduces, and it is further demonstrated by a reduction in MCH values (Ozer et al., 2008; Robinson et al., 2009; Okoye et al., 2012). This report is in agreement with the findings from this present study. Aplastic anaemia witnessed in the mice occurred in Groups V and VI administered with 900 and $1200 \mathrm{mg} / \mathrm{kg}$ b.w. extract doses respectively. It is therefore, possible that high dose of the extract must have induce anaemia in the animals which resulted from abnormalities in globulin synthesis, as can be seen from the results (table 3). In a similar situation, partial venial congestions were observed in the sections of liver, kidney, lung and testis at highest dose (Fig. 7), in contrast with those of the control group (Fig. 8). These further support the results in table 3 where decreased values of $\mathrm{RBC}, \mathrm{Hb}, \mathrm{MCV}$ and $\mathrm{MCH}$ were noticed at highest dose after 28 days of study. It can be said from the result obtained in this present study high 
dose of C. sinensis leaf extract may be regarded as toxic. Because, toxic agent is an agent that that can produce adverse biological effect in its host. It may be in the form of chemical, physical or biological.

Serum biochemical parameters are vital indices to determine the functionality of some organs in the humans especially the liver (Donga et al., 2005; Tabuti et al., 2003; Haldar et al., 2010). The liver is an organ located in the right upper portion of the abdominal cavity immediately below the rib cage. It is the largest organ in the body and plays many functions that are very crucial to life such as detoxification of blood, carry out various metabolic processes, production of clothing factors and other proteins, among other functions. In order to detect liver damages resulting from $C$. sinensis extract administration in mice, the levels of certain liver enzymes in the blood has to be evaluated (Kumar, 2019). Because, under normal conditions, these enzymes usually reside within the liver cells. Thus, any injuries to the liver will cause these enzymes to spill into the blood stream (Jothy et al., 2011; Mukinda, 2005; Aneela et al., 2011). These enzymes include aspartate aminotransaminase or transferase (AST or serum glutamic oxaloacetic transaminase; SGOT) and alanine aminotransaminase (ALT or serum glutamic pyruvic transaminase; SGPT). A damage to liver cells will result in abnormal increase in the levels of these enzymes indicating one liver disease or the other. These enzymes are not only restricted to the liver cells as AST can be found in the heart, muscles, kidneys, and brain (Raza et al., 2002; Adam, 1998; Fennell et al., 2004). From the results obtained (Fig.4), slight elevated levels of AST were witnessed at high doses of 600,900 , and $1200 \mathrm{mg} / \mathrm{kg}$ b.w. These elevated values were statistically not significant from those of the control at $\mathrm{p} \leq 0.05$ (one-way ANOVA).

Subchronic administration $C$. sinensis extract slightly increased the biochemical, serum electrolytes and lipid profiles as well as plasma glucose levels of mice after 28 days. These increase were within acceptable range, which implied that subchronic intoxication of the leaf extract of $C$. sinensis as herbal tea did not produced pronounced toxicological effects in the animals (see figs. 4, 5, 6, 7 and 8). For instance, albumin is a common proteins that is found in the blood, and it also is made only in the liver. Lower levels of albumin than the normal range of $3.5-5 \mathrm{~g} / \mathrm{dL}$ can be an indication of chronic liver disease or liver cirrhosis (Mukinda et al., 2007; Mir et al., 2013; Bello et al., 2016). The value of albumin obtained from this present study is suggestive of a good liver cell. Similarly, elevated levels of bilirubin which is a bye- product of RBCs destruction can cause liver dysfunction (Rahman et al., 2014; Bhushan et al., 2014). The values obtained in this case were at normal range $(0.1-1.0 \mathrm{mg} / \mathrm{dL})$, which is suggestive of safety profile of the plant extract (Fig.4).

Furthermore, high electrolytes levels in blood can cause electrolytes imbalance, and may be due to dehydration (Kamal et al., 2012; Ezeja et al., 2014) .High levels of sodium (Na+) and chloride (Cl-) ions obtained in this study is suggestive of injured liver, kidney or lungs (Fig. 5). In addition, increased levels of LDL (also called bad cholesterol) are reported to be associated with the development of cardiovascular disease (Ukwubile et al., 2019; Mukinda and Syce, 2007), (Fig.6). High levels of HDL which are good cholesterol were obtained in dose-dependent manner as compared to that of LDL and VLDL. Though partial organ congestions were seen in histopathological examination of organs (Figs.7 and 8), these congestions were not significantly different from those of the control group. These partial congestions may be as a result some waste products in the blood or reduced supply of bile to the level as result stone blockage (Thanabhorn et al., 2006; Donga et al., 2005).

The results from the study showed Camellia sinensis leaf extract was safe for consumption as herbal tea preparations and other products. However, there is the need to put into cognizance some of the observed side effects as well as results obtained from the biochemical analysis of blood and organs due to subchronic intoxication of high doses of the extract. This is because, the dose of an agent is an important factor in toxicology, and it has a crucial relationship with the effects experienced by the animals or individual concerned. The presence of high amount of alkaloids in the leaf from this study should be put into consideration in determining the dose of the $C$. sinensis leaf extract as ethnomedicinal prescription for disease. This is because, some alkaloids have been reported to produce lethal effects when taken in high dosage.

\section{CONClusion}

The results from this study indicate that, oral administration of Camellia sinensis leaf extract did not produce significance toxicological side effects in the mice. Therefore, the leaf extract can be used safely for herbal and other pharmaceutical preparations. However, slight abnormalities might occur at high dosages as seen from the results of the study. The presence of alkaloids in the leaf extract should also 
be put into consideration as some alkaloid containing drugs produce some levels of side effect at higher doses.

\section{ACKNOWLEDGEMENTS}

The authors are very grateful to the management and staff of Mambila Beverages Nig. Ltd Taraba State, Mr Livinus Tam of Sancta Maria integrated laboratory and Mr Bulus Auta of the Department of Pharmacology, University of Jos, Nigeria, for all the helps rendered in this study.

\section{REFERENCES}

[1] Adam SEI (1998) Toxic effects of Francoeuria crispa in rats. Phytotherapy Research 2: 476-479.

[2] Amna OF, Nooraain H, Noriham A, Azizah A, Husna RN (2013) Acute and oral subacute toxicity study of ethanolic extract of Cosmos caudatus leaf in Sprague Dawley rats. Int. J. Biosci. Biochem. Bioinform. 3:301-305.

[3] Aneela S, De S, Kanthal L, Choudhury N, Das B, Sagar K (2011) Acute oral toxicity studies of Pongamia pinnata and Annona squamosa on albino Wistar rats. Int J. Res. Pharm Chem. 1(4): 820-4.

[4] Bello I, Bakkouri AS, Tabana YM, Al-Hindi B, Al-Mansoub MA, Mahmud R, Asmawi MZ (2016) Acute and sub-Acute toxicity evaluation of the methanolic extract of Alstonia scholaris stem bark. Med. Sci. 4(1): 4 .

[5] Bhushan B, Sardana S, Bansal G (2014) Acute and sub-acute toxicity study of Clerodendrum Inerme, Jasminum Mesnyi Hance and Callistemon citrinus. J. Acute Dis.324:327.

[6] Burkill HM (1997) The useful plants of tropical West Africa. 43rd Edition, Royal Botanical Archives.

[7] Chan EWC, Lim YY, Chew YL (2007) Antioxidant activity of Camellia sinensis leaves and tea from a lowland plantation in Malaysia. Food Chemistry 102 (4): 1214-1222.

[8] Donga S, Shukia VJ, Ravishankar B, Ashok BK, Mishtry IU (2011) Chronic toxicity study of Butea mosperma (Linn) Kuntze seeds in albino rats. Ayuveda 32:120-125.

[9] Evans WF (2009) Trease and Evans Pharmacognosy 16th Edition. Elsevier Saunders, London: 603Pp.

[10] Ezeja MI, Anaga AO, Asuzu IU (2014) Acute and sub-chronic toxicity profile of methanol leaf extract of Gouania longipetala in rats. Journal of Ethnopharmacol.151:1155-1164.

[11] Fennell CW, Lindsey KL, Lyndy M, Sparg SG, Stafford GI, Elgorachi E, Olwen MG, Staden JV (2004) Assessing African medicinal plants for efficacy and safety: pharmacological screening and Toxicology. Journal of Ethnopharmacology 94 (2-3):205-217.

[12] Florence AR, Joselin J, Shyninbrintha TS, Sukumaran S, Jeeva S (2010) Preliminary phytochemical studies of selected members of the family Theaceae for bioactive constituents. Bio. Sci Disc 5(1):85-96.

[13] Haldar PK, Bhattacharya S, Kar B, Bala A, Mazumder UK (2010) Chemoprventive role of Indigofera as palathoides in 20-methylcholanthrene induced carcinogenesis in mouse. Toxicol. and Enviro Chem. 92: $1749-1763$.

[14] Hutchings A (1996) Zulu Medicinal Plants. An Inventory. University of Natal Press, Pietermaritzburg: 300 -325 .

[15] Iwu MM (1993) Hand book of African Medicinal plants. USA, Florida, CRC Press: 121-122.

[16] Jothy SL, Zakaria Z, Chen Y, Lau YL, Latha LY, Sasidharan S (2011) Acute oral toxicity of methanolic seed extract of Cassia fistula in mice. Molecules 16 (6):5268- 82.

[17] Kamal MSA, Ghazali AR, Yahya NA, Wasiman MI, Ismail Z (2012) Acute toxicity study of standardized Mitragyna speciosa Korth aqueous extract in Sprague dawley rats. J. Plant Stud. 1(2):120.

[18] Kumar GL (2019) Pathology (Ed.). Educational guide - Special staining and H \& E, 2nd edition. Dako Pub. USA.

[19] Mbaka GO, Adeyemi OO, Oremosu AA (2010) Acute and sub-chronic toxicity studies of the ethanol extract of the leaves of Sphenocentrum jollyanum (Menispermaceae). Agriculture and Biology Journal of North America 1(3):265-272.

[20] Mir AH, Sexena M, Malla MY (2013) An acute oral toxicity study of methanolic extract from Tridex procumbens in Sprague Dawley's rats as per OECD guidelines 423. Asian J. Plant Sc. Res.3:16-20.

[21] Mukinda JT (2005) Acute and chronic toxicity of the flavonoid-containing plant, Artemisia afra in rodents. M.Sc. Thesis, Department of Pharmacology, University of the Western Cape, Bellville, South Africa: 149 Pp.

[22] Mukinda JT, Syce JA (2007) Acute and chronic toxicity of aqueous extract of Artemisia afra in rodents Journal of Ethnopharmacology 112:138-144.

[23] OECD (2009) Draft Guidance Document on the Design and Conduct of Chronic Toxicity and Carcinogenicity Studies, Series on Testing and Assessment No. 116. 
[24] Okoye TC, Akah PA, Ezike AC, Okoye MO, Onyeto CA, Ndukwu F, Ohaegbulam E, Ikele L (2012) Evaluation of the acute and sub-acute toxicity of Annona senegalensis root bark extracts. Asian Pac. J. Trop. Med. 5:277-282.

[25] Olorunnisola OS, Bradley G, Afolayan AJ (2012) Acute and sub-chronic toxicity studies of methanolic extract of Tulbaghia violacea rhizomes in Wistar rats. African Journal of Biotechnology 11(83):1493414940.

[26] Ozer J, Ratweb M, Shawc M, Baileya W, Schomaker S (2008) The current state of serum biomarker of hepatoxicity. Toxicity 245:194-205.

[27] Rahman HS, Rasedee A, Othman HH, Chartrand MS, Namvar F, Yeap SK, Abdul SN, Andas J, Muhammad NN, Anasamy T (2014) Acute toxicity study of zerumbone-loaded nanostructured lipid carrier on $\mathrm{BALB} / \mathrm{c}$ mice model. Bio Med Res Int. 5:15.

[28] Raza M, Al-Shabanah OA, El-Hadiyah TM, Al-Majed AA (2002) Effect of prolonged vigabatrin treatment on hematological and biochemical parameters in plasma, liver and kidney of Swiss albino mice. Scientia Pharmaceutica 70:135-145.

[29] Robinson S, Chapman K, Hudson S, Sparrow S, Spencer-Briggs D, Danks A,Hill R, Everett D, Mulier B, Old S (2009) Guidance on dose level selection for regulatory general toxicology studies for pharmaceuticals. London: NC3Rs/ LASA.

[30] Saidu Y, Nwachukwu FC, Bilbis LS, Faruk UZ, Abbas AY (2010) Toxicity Studies of the crude aqueous root extract of Albizzia chevalieri Harms in albino rats. Nigerian Journal of Basic and Applied Science 18(2):308-314.

[31] Sofowora A (2006) Medicinal Plants and Traditional Medicine in Africa. Spectrum Books Ltd, Ibadan: 123.

[32] Tabuti JRS, Lye KA, Dhillon SS (2003) Traditional herbal drugs of Bulamogi, Uganda: plants, use and administration. Journal of Ethnopharmacology 88(1):19-44.

[33] Thanabhorn S, Jenjoy K, Thamaree S, Ingkaninan K, Panthong A (2006) Acute and subacute toxicity study of the ethanol extract from Lonicera japonica Thunb. Journal of Ethnopharmacol. 107:370-373.

[34] Thapa BR, Walia A (2007) Liver function test and their interpretation. Indian Journal of Paediatrics 74: 663671.

[35] Thierry DTA, Asongalem EA, Nana P, Choumessi A, Tazoacha A (2011) Sub-acute toxicity study of the aqueous extract from Acanthus montanus Djami Tchatchou. Electronic J. Biol. 7(1):11-15.

[36] Ukwubile CA, Ikpefan EO, Bingari MS, Tam L (2019) Acute and subchronic toxicity profiles of Melastomastrum capitatum (Vahl) Fern. (Melastomataceae) root aqueous extract in Swiss albino mice. Progress in Chemical and Biochemical Research 2(2): 74-83.

[37] Ukwubile CA, Samagoro CT, Nuhu A (2018) Preliminary phytochemical screening and acute toxicity determination of Camellia sinensis L. (Theaceae) leaf methanol extract in Swiss albino mice. International Journal of Biological Sciences and Research 1(1): 1-17.

[38] Wang ZG, Ren J (2002) Current status and future direction of Chinese herbal medicine. Trends in Pharmacological Sciences 23(8):347-348.

Citation: Cletus.A. Ukwubilela, et.al., (2020). Phytochemical Composition and Toxicity Evaluation of Camellia Sinensis (L.) O.Kuntze (Theaceae) (Green Tea) Leaves Collected from Mambila Beverages Ltd Nigeria. International Journal of Medicinal Plants and Natural Products (IJMPNP), 6(2), pp.7-13. http://dx.doi.org/ 10.20431 /2454-7999.0602002

Copyright: (c) 2020 Authors, this is an open-access article distributed under the terms of the Creative Commons Attribution License, which permits unrestricted use, distribution, and reproduction in any medium, provided the original author and source are credited. 